\title{
Criticism in Public Sphere: The Press Development in Iran's Civil Society 1997-2000
}

\author{
Vahid Amani Zoeram \\ Faculty of Human Ecology, University of Putra \\ Lee Yok Fee (Ph.D) \\ Faculty of Human Ecology, University of Putra
}

\begin{abstract}
From 1997 to 2000 Iran witnessed a flourishing evolution in the printed media. Reformists' main agenda on civil society predisposed appropriate conditions for the expanding of press in Iran, both in quantity and quality characteristics. This article examines some important changes on the press to show how the press helped to develop critical public sphere in Iran during that time. Research outcomes show that many of the political and intellectual debates that considered as taboos and were not to be discussed at once, were changed to public issues and were criticized by the press in the public sphere of Iran's society, and this was a great advantage for the Iran's civil society.
\end{abstract}

Keywords: Iranian press, Khatami, Public sphere, Reformists, Conservatives

\section{Introduction}

This article attempts to answer to the following questions: what was the role of the press, particularly in the form of newspaper and magazine in the development of civil society and public sphere during the President Khatami's first tenure? How did the press help to form a new critical public discourse in Iran's society during that period? In an ideal democratic society, newspapers and publications should enjoy more freedom and in preserving their independent from the political structure. This is crucial in ensuring their functions in the stage of public sphere and civil society. Thus, this study investigates the predominant evolutions of the press which indicates the emergence of new critical sphere in Iran's society during Khatami's presidency.

\section{The role of the press in modern societies}

Mass media plays ideal role in a democratic society that enables an informed citizenry to make decisions for common good (Kumar, 2001, p. 285). Hagerman's debates on deliberative democracy, public sphere, life world and communicative power, demonstrate the role of mass media particularly the press in modern democratic societies as well as in developing countries. Echo to this, Habermas presents deliberative model of democracy as an alternative to both liberal and republican models (Vitale, 2006). And communicative power is a central notion in this model of democracy which can develop only in unreformed public sphere. Also communicative actions construct the life world where it is possible to colonize by money and power systems. Public sphere as a social area that is created by and for communication is unorganized, but it is civil society and its components such as associations and movements which anchor the communication structures of the public sphere in the life world (Flynn, 2004).

At the periphery of the political system, the public sphere is rooted in a networks of wild flows of messages such as news, reports, commentaries, talks, scenes and images, and shows and movies with an informative, polemical, educational, or entertaining content (Habermas, 2006). Media experts create an elite discourse, provided by actors who struggle for access to and influence on the media. They enter the platform from three points, i.e. politicians and political parties start from the center of the political system; lobbyists and special interest groups come from the vantage point of the functional systems and status groups they represent; and advocates, public interest groups, churches, intellectuals, and moral entrepreneurs come from backgrounds in civil society" (Habermas, 2006, p. 417).

Media power as a new form of power is based on the technology of mass communications that shape to minds through public opinions. In order to prevent of distorting the formation of considered public opinions, it needs the established rules to constitute the right game. Habermas (2006, p. 420) asserts that "for the rules of the right game to exist, two things must first be achieved, first, a self-regulating media system must maintain its independence vis-à-vis its environments while linking political communication in the public sphere with both civil society and the political center; second, an inclusive civil society must empower citizens to participate in and respond to a public discourse that, in turn, must not degenerate into a colonizing mode of communication". 
Therefore civil society, media and public sphere are three pillars of sustainable democracy. The press at least has two functions in democratic society, first, as a component of civil society protects all citizens against state power and transfers individuals' demands to political system; and second, it shapes the public opinion in public sphere.

Mass media, particularly the press is responsible for the special task of exchanging and circulating awareness and information which are vital elements in every open society. Awareness and freedom are integral components of a democratic society and it is for the same reason that the 20th century totalitarian governments, including Nazism, Fascism or Communism, took action in limiting and controlling the mass media before doing anything else. The mass media causes plurality of information and spread information around the society while they, themselves, reflect the variety of ideas in a democratic society. The media is able to do its real mission as a mediator between the government and society, if it is not monopolized by the ruling power. In an ideal civil society, the media is not under the inclusive control of government or a certain group; rather all real and legal individuals can have them in their possession according to and in the framework of laws (Mohammadi, 1999, p. 53). Monopolizing the media equals to monopolizing thoughts, and monopolizing thoughts leads to a closed nondemocratic society in which dialogue and understanding replaces with single-voicedness and delusion (Mohammadi, 1999, pp. 52-53). Thus the press provides a free communicative atmosphere, far from pressures and controls exerted by the government, where citizen's real public opinions are formed.

When considered as the criterion indicating the development of civil society and public spheres, the media is evaluated by its quality rather than its quantity. Quality, here, means attention paid to the media ownership, its independence, the degree of freedom and job security of the personnel and employees, the content of the media and so on. Otherwise, a totalitarian society could also be considered as one with numerous media, but in such societies the media is supposed to be: the origin of legitimizing and influencing, the agent through which the government's demands are transmitted to the public and the public's obedience and allegiance are transmitted to the government, and the only official loudspeaker announcing and imposing the government's idea and viewpoints on the people (Mohammadi, 1999, p. 52). In defining criteria like welfare, security, freedom and national interests, the independent media is announcers of the demands of the society and its various groups, but the dependent media defines these concepts in a way that leads to maintaining the ruling system's stability and preserving its interests (Mohammadi, 1999, p. 92). Also, criticizing the present situation and existing structures are two of crucial functions of the mass media. Criticism as a tool tears apart any iron wall of sacredness and uncriticizability that immunes agencies and individuals in power and leaves them open to defend their own plans and actions. Thus, in an ideal civil society in which the independent newspaper and magazines have the possibility to supervise and criticize those in power, the sphere of politics and even economics become clear and the ruling power, in every layer, becomes responsive to the society.

The expansion of cultural and political freedom that followed the election of Khatami as Iran's president was a crucial factor in qualitative and quantitative development of the printed media after 23 May 1997, and many unorganized social forces in the form of civil institutions found the media as a suitable context for their activities. Indubitably the press was considered as the first and the best forerunner institutions in Iran's civil society. Therefore, the first part of this article studies the quantitative improvements the press at that time. And the second part explores the most important achievements and influences of developing the press particularly the discussions and criticized spheres in the press as the public sphere at that time.

\section{A historical review on the press in Iran}

The growth and development of the newspapers are dependent on the political condition and an open atmosphere for democratic political activities. Yet, newspapers are the most vulnerable institutions of civil society in front of the ruling power. By now, it is nearly more than a century that newspapers have been published in Iran. However, except for the three short periods, there have been no opportunity to develop the press while in each period of freedoms the press could not strengthen their foundations in the society hence with the appearance of a powerful government were immediately suppressed and shut down. Kaghaz e Akhbar was the first newspaper which first published in 1837. And the Constitutional Revolution in 1907 had prepared the first period of the development of the press in Iran. The press had an important role in political competitions particularly in the process of making new constitution in that time (Zakerhossein, 2005). Soresrafyl, Mousawat, Majles, Roholghodos, Ghanoon, and Hablolmatin were some of the famous newspapers during the constitutional era. No matter how, Reza Khan's Coup-d'état in 1921 had put an end to that period. Suppression and limitations of the press by Reza Shah had continued for 20 years. Occupation of Iran in 1941 and downfall of dictatorship regime predisposed conditions for expansion of the press that helped the National movement in the procedure of struggle for oil nationalization. Zahedi's Coup d'état in 1953 ended this period and began a new era of control and repression against the press (Zakerhossein, 2005). Islamic Revolution was a new opportune for the press freedom but it did 
not last long. During the three years following the Islamic revolution, the plurality of political groups and the open political atmosphere increased the press circulation to a great deal. However, they were not immune from the consequences of the closure of the political atmosphere and limiting the socio-political freedom. As a consequence, most of the criticizing press which opposed the contemporary ruling power was shut down. But it should be noted that the journalistic atmosphere of the time was mostly under the influence of political groups and when these groups came to their ends, the press lost their prosperity as well. In the beginning of war in the early of 1980 s, political suppressions and ideological regime ended to the press freedom in Iran for a decade. The period after war and outset of the economic reconstruction was a new era for developing the critical magazine and newspapers such as Iran e Farda. In 1990, the number of the printed materials experienced a growth of $49 \%$ in the quantity of newspapers (Salam Daily, 7 April 1997, p. 9). According to the statistics, between 1979 and 1983 only 7 newspapers were published in the country. The number increased to 34 in 1993 and 62 in 1996, but the most important phase that marks the growth in the quantity of papers is the period after 23 May 1997.

\section{Quantitative Changes of the Press after 23 May 1997}

When Khatami selected Mohajerani who was a reformist journalist, as a Ministry of Culture and Islamic Guidance, the political conditions became better for developing the critical and independence press. According to Norouz daily (No. 17), the number of newspapers in this period was 112 and 1999 was marked by the highest rate of permit nullification in a year. During these years, the permits of 78 publications were nullified and 57 publications were shut down (Fateh Daily, 3 April 2000, p. 4). Though there is a shutting down of 16 newspapers in a single action by the judiciary system, instead the numbers increased greatly. In addition to the newspapers, statistics indicate an increase in the figures related to all periodicals after 23 May 1997. While the highest growth in the number of periodicals during 1980s was recorded in 1990 as $49 \%$, the number of periodicals during the time reached to 274 and continued to increase up to 700 (Salam Daily, No.1688, 6 April 2000, P.9). But, according to Norooz Daily, from the total 1611 permits issued for publications running in 2001, 927 permits were issued after 23 May 1997. Because of the suitable atmosphere for the development of thoughts and ideas, the requests for establishing new publications has increased to 2200 in 2001 (Norooz, No. 115, 25 August 2001, p 3). Figure $1 \& 2$ demonstrate a notable expansion in the number of the press particularly in newspapers in the first three years of Khatami's presidency. In addition, the number of newspaper copies print each day is another criterion which shows a great increase in this period. While, before 1997, the number of copies published each day were less than one million copies per-day (Salam Daily, No. 1705, 8 May 1997, P.5), the total number of both national and local newspapers was estimated to be more than two and a half million copies per-day (Aftab Yazd Daily, 13 May 2001). The regrettable point is that with all these, the ratio of newspapers to Iran's population is even less than the same ratios in some neighbor counties like Saudi Arabia and Kuwait. While Turkey, as one of the neighbor countries, had 112 copies per 1000 inhabitants and holds a better stance in comparison, Iran stood 114 in the world with only 24 copies per 1000 inhabitants in 2000 (Entekhab Daily, No. 311, 8 May 2000, P.6).

As statistical facts show, in an attempt to change the motto of civil society into practice, the government led by President Khatami made the befitting conditions needed for quantitative growth of the media after 22 May 1997, a rare event in the past one hundred years and at a time when a powerful and well-established government was running the country. Generally, the open political atmosphere for the media was made at that time due to some internal and external factors which caused the government was not strong enough for power exertion. However in the development of the press, there was a qualitative change, as defined by Habermas, which increased of civil values and developed the atmosphere for free communicative action. The next part of this article explores this change in the quality of the press.

\section{Qualitative Changes of the Press after 23 May 1997}

\subsection{Development of Independent Newspapers}

According to Aftab Yazd daily, after 23 May, 85\% of newspaper permits were owned by the private sector (Aftab Yazd Daily, 13 May 2001, p.9). This, on one hand, was an indicator of the growth and development of civil society in Iran that was financially capable of running this amount of the press while having enough professional personnel. And on the other hand, it was a sign that social forces, preferring to struggle in a legal framework instead of resorting to illegal and violent ways, had found the press as an appropriate tribune to express their requests and interests. It also indicated that the government had taken effective steps to decrease its own role in running the press. While the ministry of Culture and Islamic Guidance was itself a part of the ruling system, it showed its firm determination to develop the press both in words and action and even proved to be a strong 
defender of the press against a part of conservative forces that attacked them. It explicitly expressed that "we will use all available tools to defend the press" (Jame'eh Daily, No. 58, 4 May 1998, P.9), and in response to the conservative's accusations towards the press, it declared, "our press respect law and follow the rules established by law and the saying that the newspapers and publications have endangered national security is improper, incorrect and the outcome of personal ideas" (Salam Daily, No. 2002, 3 May 1998, P.2). The reduction of the government's control over the press showed itself in the process of selecting, nominating and refereeing the published works in the press festivals that took place annually. Since 1998, all these responsibilities were passed to the Press Syndicate as a non-governmental civil institution (Jame'eh Daily, No. 58, 4 May 1998, P.14).

During 1980s, Salam, Jahan-e-Islam, and Resalat were considered as non-governmental newspapers. They were few in number but the majority of people in charge of these papers were influencing figures in the official structure of power. However, with the new political and cultural atmosphere in the country, the number of independent newspapers increased fast. Jame'eh, as the first newspaper of the civil society, was published in 1998 and followed by new newspapers, namely Farda, Khordad, Sobh-e-Emrooz, Mosharekat, Javan, Jebhe, Aria, Zan, Hayat-e-No, Azad, Neshat, Toos, Bahar, Norouz, Shalamcheh (weekly published), Partow, Seday-eEdalat, Syasate Rooz, Aftab Emrooz, Aftab Yazd, Jame'eh Madani, Rah-e-No(weekly magazine), Mardom Salari, Mellat, Fateh, Asr-e-Azadegan, Bayan, Rouz-e-No, Aeeneye Jonoob, and etc. Although some of these were already being published locally or in limited numbers, they managed to expand their activities in the new atmosphere. Many of these newspapers are presently banned and most of them are undergoing a trial by the judiciary system with accusations like acting to mislead public minds, sacrilege, and so on. As such 90 percent of bans were against the press in privet sector (Aftab Yazd Daily, 13 May 2001, p.9). All these show that the extent of the non-governmental newspaper's vulnerability against the ruling power.

\subsection{Changing into Critical Press}

Prior to 23 May 1997, most of the newspapers were either governmental or needed government to protect and support them financially. Hence, they were less critical. Moreover, the political atmosphere did not let them to be critical and those who criticized were accused of being mercenaries, hypocrites and irreligious. Essentially, authorities knew themselves as immune, far from any fault and free from any need for criticism. But with Khatami's victory in the election and his action in accepting criticism, and encouraging his colleagues to accept criticisms from the press, too, found a new characteristic and gradually, in the words of Jalayeripour, "an opaque atmosphere to criticize, though a shaking one" appeared between the society and authorities.

Journalists and writers were forerunners of making a general atmosphere for criticism in the sphere of civil society after 23 May 1991. A glance at the headlines and editorials on different newspapers revealed that many political, social and even religious taboos were being criticized while no person or group, even newspapers and writers themselves, were immune from these all-encompassing criticisms. The performances of authorities and political wings, existing laws and different interpretations of religious tenets were among the most popular subjects of criticisms. The collection of critics included people from all political wings and independent individuals.

The untouched areas that the newly established atmosphere of criticism found an access to included prominent political figures such as Rafsanjani, Khatami, Velayati, and Mohammad Yazdi who during the twenty years after the revolution and despite their outstanding roles in political changes and the fate of the Iranian society were less exposed to criticism. Before President Khatami's tenure, few people could criticize the president's position, but in the newly created atmosphere these positions and figures lost their halo of sacredness and had to answer what they had done. Criticizing Hashemi Rafsanjani, while was important for its own sake, had a greater significance in paving the way for criticizing those who were less prominent than him. Such criticism was like falling the first block of numerous blocks in a domino game. At that time, no one could escape the sharp edge of criticism and/or consider himself outside the limits of criticism. The advantage of this atmosphere was that criticisms and dialogues were reciprocal, i.e. critics and defendants. Each of them had his or her own tribunes, though the Conservatives had access to and was equipped with state radio and television stations and Friday Prayer's tribunes, through which expressed their viewpoints.

Another characteristic of the new critical atmosphere was the criticizing phenomena and events that were supposed to be sacred and untouchable. The most important example was the war between Iran and Iraq and the manner of its management during eight years of fighting. At that time, the war was expected to be praised as an epic but it was then taken as a political and real phenomenon that could have possibly ended in greater advantages for the country if it was managed differently. This meant that all strategies and courses of actions 
during the war had not been necessarily correct and the mistakes committed by the administrators which had brought disadvantages for the country, should be answered before the people.

In addition to the holy defense, subjects like the Construction Era, the action of the Ministry of Culture and Islamic Guidance, broadcasting organization, the Tehran Municipality, judiciary system, the Fifth Parliament, the Expediency Discernment Council, the Guardian Council, the Assembly of Experts, the High Council of Cultural Revolution, the Institution of the Clergy, the president, police force, Guard Corps, the press, and the Ministry of Foreign Affair were amongst areas that were exposed to criticism and had to defend their actions.

Besides, internal criticism was another crucial outcome of this new atmosphere of criticism too. Many writers, strategists and members of new parties began to criticize some of their own internal actions and policies in a way that they even presented a pattern of criticizability to their opposition groups. Both reformists and conservatives wrote articles in which they mentioned their weaknesses and this was a precious gift to Iran's culture that would not usually yield to criticism. Therefore, little by little a critical cultural atmosphere appeared that had no room for sabotage and violence which were, at least, considered unbecoming.

Moreover 23 May 1997 was an opportunity for beginning a series of fundamental discussions around important problems of Iranian society. With the expansion of open political and cultural atmosphere and along with the vogue for the press and the prevalence of discussion among various political and ideological wings and groups, some pivotal and important subjects were introduced to the society for the first time. Although the expression of these ideas and views had overwhelming expenses such as detention, imprisonment or deprivation from social rights for many of those who expressed themselves, the creation of such atmosphere and the introduction of these issues were altogether to bring benefit of the Iranian society and could be considered as one step further towards clearing the political and mental atmosphere. Expressing their views, many individuals and groups revealed their true identity and as a result the society found appropriate measures and criteria to judge different people and different groups.

In this part, along with a brief introduction of some of the most important trends exposed in these debates, author endeavored to reiterate the views of pros and cons and the logic behind their reasoning. Since most of these discussions were printed in the contemporary press, in order to explore this subject we can refer to the articles and books published by the writers who had an active role in the discussions of the time. Having a quick glance at the various headlines and articles in the publications of different ideological groups after 23 May, we notice that each of these groups had its own theoreticians whose thoughts were presented to people through a collection of its related publications. In the rest of the article we explore some of the most important ideological controversies presented in publications and newspapers of that time and present the views of their pros and cons.

\subsubsection{Guardianship of Islamic Jurists}

\subsubsection{Election or Appointment}

One of the most important and pivotal subjects in political and ideological controversies aftermath 23 May was contemplating on the subjects of election or appointment with regard to the position of the Guardianship of Islamic Jurists. Some groups, based on a certain interpretation of Constitution knew the Jurist (Vali-e-faqih) as being appointed by the holy religion and considered the people's indirect vote as only a way to unearth the true case. On the other side was another group, who based on a different interpretation of the Constitution and relying on rational and religious reasons, put emphasize on the theory that supported election in choosing the one who holds the position of the Jurist. These groups, however, cannot be simply divided into two groups who supported either election or appointment in identifying the Jurist. The reason is that each one of these groups - because of their own specific reasons - measured people's votes in their own way. Thus it can be said that those who entered the controversy were located somewhere on the line that started with the absolute belief in appointment and ended with an absolute belief in election in the process of the Jurist's identification.

The supporters of appointment of Jurist (Vali-e-faqih) believe that at the time of occultation, a jurist who possesses all the qualities stated in narrations (Hadith), has the right to rule and according to some of the narrations is appointed to rule by the immaculate Imams. The legitimacy of the jurists' rule comes from their appointment by immaculate Imams who, in their turns, are appointed by God. People must recognize (unearth) and follow them to execute the religion (MesbahYazdy, 1998). By appointment this group means that at the time of occultation, the jurist who possesses the scientific and practical qualities is appointed by the immaculate Imams to a position where he possesses the rights of decree, judge and guardianship. Appointment means the possession of the title of the position and designation and differs from qualities' announcement. In the procedure of decree, judge, and guardianship Muslims do not choose the jurist to be their attorney in obtaining decrees or understanding and executing judicial orders. The guardianship which is considered the third aspect of his 
position is the same, therefore Muslims do not make the jurist their attorney to rule (Amoli, 1999, p. 389). The guardianship and Islamic rule comes from the God and it is Him who lets someone to interfere into others' lives and possessions (MesbahYazdy, 1998, p. 18). The highest value considered by the supporters of this theory for people's vote is that people are just the tool making for the rule of guardianship (Vali-e-faqih). Separating legitimacy from acceptability they also believe that legitimacy comes from the appointment by God and acceptability is an effect of this selection. Thus with or without people's vote the jurist is both legitimate and appointed and whereas he may have not the exposure of this power, people's vote just gives a plain exposure to this power assigned to him (MesbahYazdy, 1998). The most outstanding defenders of this theory were newspapers like Resalat and Keyhan, and writers like Javadi Amoli, Ayatollah Mesbah Yazdi, Khazali, Mohebbian, among others.

By contrast, those in favor of election procedure believe that political guardianship is based on allegiance. And allegiance is a kind of two-headed contract with two sides: the ruler and the people. This two-headed contract is dependent on foundations and rules that both parties in the contract have to observe (Aghajary, 2002, p. 25). Satisfaction is part of the people and responsibility is part of the rulers and towards people to whom they owe the debt of assigned power to rule. Accordingly, here it is impossible to separate legitimacy from acceptance because legitimacy comes together with acceptance (Hajjariyan, 2000a). Thus according to this group, Shiite jurisprudence and the Constitution know the position of guardianship of the jurist as an elective one and it is unacceptable to say that people just enter to prove it and give it acceptability, higher than that the legitimacy of the guardianship of the jurist depends on the right of national sovereignty (Hajjariyan, 2000a) and people's satisfaction is not only a requisite to the acceptability of the leadership and Islamic ruler, but is also a requisite to the "legitimacy" of leadership and Islamic ruler (Kermany, 2001). The most outstanding advocates of this theory were Asre-e-Ma publication, and the newspapers were known as reformists' newspapers as well as figures like Hajjarian, Aghajari, Abdi and others.

Some scholars, however, tried to take the middle ground. They accepted the appointment in regard to the position of the guardianship of the Jurist, but they considered the people as a requisite to its legitimacy. Paying attention to the answer of Ayatollah Khomeini to a letter from the Secretariat of Friday Prayer's Imams, Mostafa Kavakebian, it could be concluded that the ruling of a Jurist enjoys a legitimacy that comes from both God and people. In that letter Imam Khomeini had stipulated that the guardianship of Muslims' affairs and establishing a ruling system depend on the votes of the majority of Muslims as it is stated in the Constitution and was known as allegiance to the Jurist in the early period after Prophet Mohammad was given the mission (Kavakebiyan, 1999).

\subsubsection{The Relationship between the Position of the Jurist and the Constitution}

One of the most important questions put forward in the newspapers after 23 May 1997 was the relation between the position of the Constitution and the institution of the guardianship of the Jurist. On this debate, some consider the Constitution as "the guarantor of survival and consolidation of the position of the guardianship" and therefore they regard the institution of the guardianship as possessing legitimacy and authority in the framework of the Constitution. On the other side, another group who believe that guardianship is the guarantor of the survival and consolidation of the Constitution and regard the legitimacy of the Constitution an outcome of the Jurist's existence.

The first group Interpret the Constitution as a document of national allegiance and consider the constitution as the guarantor of the legitimacy of the Islamic system and believe that the Jurist is elected based on the mechanisms designed in the Constitution and must not be considered the position of the guardianship as superior to the Constitution. Thus because the position of the Jurist is a position occupied based on election in the framework of religious measures, the Constitution is the only guarantor of the guardianships' consolidation. These theorists believe that by proposing the superiority of the guardianship's position, the obedience towards it presupposes coming to believe it and this puts the guardianship in parallel with other theories of government in Shiite's jurisprudence, where no reason could be found to follow it (Asr-e-Ma, No.83, 26 Oct. 1997). Relying on the preface to articles 56 and 177 of Constitution, this group believes that the Constitution is the guarantor of the type of the government, the mechanism of Jurist's election and the Jurist's responsibilities and limits of power and its denial leaves no legitimacy for the institution of guardianship and the government. Particularly in article 177 it is emphasized that "the democratic character of the government as a republic, the vilayat al-'amr and imamate of ulammah, and the administration of the affairs of the country based on national referenda, official religion of Iran [Islam] and the school [Ja'fari] are unalterable." It means that even the Jurist (valie-e-fagih) has no right to alter these principles. Also, if we know vilayat-e-Faqih as the guarantor and superior to the Constitution, then what happens to the eight million peoples from other religions and faiths? Are they considered as minorities? Without relying on Constitution and its respective articles can we expect obedience on their part? 
(Asr-e-Ma, No.85, 17 Dec. 1997) It is also stipulated in the article related to altering Constitution, article 177, that after altering the constitution, except for the articles that even the Jurist cannot alter them, and after the Leader's endorsement, it should be ratified by the vote of the absolute majority of the people to be ready for execution, otherwise it would be devoid of any executive value. Thus, the Jurist cannot be superior to the Constitution and cannot be considered as legitimacy-maker for the Constitution. On the contrary, the Constitution is the origin of the legitimacy through people for the position and institution of guardianship (Hajjariyan, 2000b).

In contrast, the other group who answers the question and relies on some preliminaries believes that the existence and stability of the Constitution depend on the position of the guardianship and that the legitimacy of the Constitution depends on the jurist's confirmation. According to this group, a jurist is appointed by God and people have no role in giving legitimacy to him. In addition, no one can delimit a jurist that is appointed by God. "Whereas the Constitution is originated from human mind, it is devoid of any religious credence and to find that it should be ratified by the Jurist, himself, otherwise it is null and void. Definitely, whatever ratified by the Jurist cannot make any limitation for him at all" (Saleh, 2000, pp. 35-36). "The Constitution is the tool in the hands of the Jurist to administrate the society's affairs and cannot, ever, be the guarantor of existence and stability of the Jurist. On the contrary, it is the Jurist that legitimizes the Constitution and this legitimacy causes the obligation to practice it; that is, people consider it as a religious decree to be followed. If this legitimacy is ruled out then the Constitution is nothing rather than a collection of waste papers devoid of any credence" (Saleh, 2000, p. 36).

\subsubsection{The Limits of Jurist's Authorities and Responsibilities}

One of the most important grounds to talk about guardianship is the limits of authorities and responsibilities assigned to this institution. Majority of the discussions were related to the question of the character of the Jurist as having the quality of being or not being "absolute", and the literal and connotative meanings of the word "absolute." In fact, here, the question is that if the authority of the Jurist is determined in the framework of the Constitution or not. And that what is the real meaning of the word "absolute" which added at the time of revision in article 57 of the constitution. The main problem in this discussion is that in the article 110 of Constitution, the responsibilities and the authority of the leader are ascertained in 11 parts. While in article 57, the absolute character of the Jurist is stipulated. Thus each of these groups which is relying on one certain interpretation of the narrations, considered the authority of the Jurist as either on the highest or the lowest level.

Those who support the absolute authority of the Jurist believe that there is a ratified article in the Constitution that pronounces the authorities and responsibilities of the Jurist. But the cases mentioned in the article 110 are issues that are usually needed and do not restrict the Jurist's authorities to those cases mentioned. For the absolute guardianship of the Jurist is stipulated in another article. Thus, these two articles are not contrary to each other. The article 110 has mentioned some significant and necessary things and article 57 is for unforeseen cases and the Jurist should decide on them (MesbahYazdy, 1998, p. 57). On the other hand, there is no reason mentioned in religious text indicating limitation in the authorities of the Jurist except for the religious measures and the framework of Islam. When it is proved that at the time of occultation of Imam (Gheibat) the right of ruling and guardianship belongs to the Jurist "that mean; it is the Jurist who commands, orders and forbids, and administrates the society's affairs. People have to obey such Jurist, just like the time when the immaculate Imam was himself present and appointed somebody to do something and people had to obey his orders[...] at the time of occultation (Ghaibat) that the Jurist is appointed by the immaculate Imam to rule over people any obedience or disobedience in part of the people symbolizes the acceptance or rejection of the immaculate Imam himself" (MesbahYazdy, 1998, p. 64). Thus, the absolute guardianship is a particular term in religious jurisprudence that looks at the sphere for practicing the guardianship and those under the guardianship's command (the followers), and rejects any limitation whatsoever, but it does not mean that there is no limitation or regulation since the religious measures are the most important present measures (Hadavi, 2002). Some of the supporters of these theories believe that "when the absolute guardianship is not absolute, it is not practical at all" and being absolute has priority on being religious and it is a rational and common requisite for exercising of guardianship (Hajjariyan, 2000a, p. 276). In brief, the supporters of this theory, with a more or less equal understanding of guardianship's absolute character, know that the Jurist is free from any limitations and hindrances except for the religious measures of Islam, and knows that there is no limit for his authorities.

On the other side, stands a group that believes the non-regulated absolute obedience contrary to the religious measures and teachings and considers it as an illogical and impossible thing in the realm of social affairs. According to this group, "if some people bear in mind that in Islamic ruling system the ruler is just under the supervision of God, and not under the supervision of people or legal institutions, or make the supervision ceremonial to shut people's mouths, then the ruling is neither the ruling of a Jurist nor the ruling of Islamic 
Republic" (Roodi, 1999, p. 158). In such situation, the ruling system is not Islamic Republic. This group believes that the absolute character of the guardianship jurist in the limits of his authorities is the outcome of the votes of the majority of people. Thus, being absolute means superiority over any single primary and secondary religious commandment. However, since the Guardianship of the Jurist system (as a ruling system) able to execute its own decrees through people's vote and the Constitution therefor, it is law-bound and executes its authorities through various institutions (Hajjariyan, 2000a, p. 274). In none of the Constitution's articles the word "absolute" is used in a declarative form. Instead "the absolute guardianship of affair" is used as a counselor and even that is immediately bound with "according to this constitution's articles in the future." Also the Article 56 stipulates that the right to determine the fate of the human being is bestowed on him by God according to this article: "Absolute sovereignty over the world and man belongs to God, and it is He Who has made man master of his own social destiny. No one can deprive man of this divine right, nor subordinate it to the vested interests of a particular individual or group. The people are to exercise this divine right in the manner specified in the following articles'. Also considering the article 110 this group believes that this article has come to enquire on the responsibilities and authorities of the leader and has limited him to 11 cases" (Hajjariyan, 2000a, p. 273).

The noticeable point in these debates was that each side knew its understanding and interpretation of the constitution in parallel with and according to the views of Imam Khomeini. Yet, this was not only limited to the issue of guardianship. As for example, when trying to prove the absolute character of guardianship's authority, Mesbah Yazdy cited from Imam Khomeini's speeches and writings and then came to the conclusion he was looking for: "in all affairs related to the government, all that is considered as the responsibilities and authorities of the Prophet and Imams after him, God's blessings be upon them all, is valid about the fair Jurist" (Imam Khomeini, Bei [The Sale] p. 33-34 cited in (MesbahYazdy, 1998)) or "at the time of occultation the Jurist has the same all-encompassing guardianship as the innocent Imam himself" (Bei [The Sale], p.41 cited in (MesbahYazdy, 1998). Also, Mesbah Yazdy considers Imam Khomeini's life with regard to his practical performance in some issues as a reason for the position and authority of the Jurist, for instance, the appointment of Bazargan as the head of the provisional government in whose charter it is stipulated that appointing him, "I am a human that because of the guardianship granted to me by the holy religion I put him in the position" or attracts attention to the explicit use of the word "appoint" in the confirmation of the presidential orders issued for Banisadr, Rajaee, Khamenei, and the order to establish the Expediency Discernment Council that took place despite the fact that it was not according to Law. Thus, as Mesbah Yazdy states, all these cases are reasons for the absolute character of the Guardianship's authority according to Imam Khomeini's views.

It is interesting that, in opposition, Hajjarian examined the speeches and performances of Imam Khomeini and made another interpretation of the absolute character of the guardianship Jurist. Note the following cases: when disagreements on various issues appeared between The Islamic Consultative Assembly and the Guardian Council and made the system inefficient, Imam Khomeini proposed to make use of secondary commandments and passed the responsibility of recognition to two third of the parliament members. In the next step, Imam Khomeini put the issue of government's authority forward and answering to a letter by the contemporary prime minister enquiring about pricing wrote: "You are free to do pricing as before, do it strongly, to execute regulations and determined prices you can make use of governmental punishment [Ta'zir]." But due to some resistances, the disagreements between the Consultative Assembly and the Guardian Council were again intensified over the Labor Law. The problem of the Labor Law was solved upon issuing a decree in part of Imam Khomeini who answered the letter written by the contemporary President wrote: "to rule is a branch of the absolute guardianship of the Prophet and is one of primary commandments of Islam superior to all minor commandments even prayer, fasting and pilgrimage to Mecca (Hadj)." Later in response to the letter written by the secretary of Guardian Council enquiring on the government's authorities, he wrote: "whatever said, that, as it is rumored, leasing and bailment and the like would be disappeared with these authorities (Government's authorities). I stipulate that if it is supposedly like that, it is one of the Islamic government's authorities" (Hajjariyan, 2000a). The conclusion is that, Hajjarian accepts all these evidences as the reasons to the absolute authority of Islamic government or the Guardianship when considered as an institution and not as an individual that holds the position.

Therefore, in spite of common sources like Constitution, narrations and sayings, the practical model, and Imam's speeches and writings each party in the debates selected certain parts of the sources and came to a certain interpretation of the issues about which they quarreled in writing.

\subsubsection{The Experts Assembly and the People's Votes}

One of the subjects to discuss the issue of the guardianship Jurist is the level of people's value and their effect on legitimizing the position of guardianship and the Experts Assembly, their authorities and responsibilities, and 
their relation to the guardianship Jurist. Based on the answers given to these questions two groups arrayed opposing each other.

The first discussion focused the question, "what is the function of the Experts Assembly?" One viewpoint saw the Experts Assembly's function as the recognition of a qualified Jurist. The supporters of this view believed that in the Islamic political system the substantiality of the Leader's words does not depend on the people's vote and the validity and the legitimacy of both system and the Jurist is not the offspring or the outcome of the expert's vote. The reason is that the guardianship is not granted to the leader; thus, the expert's task is to recognize a Godly leader whose characteristics are determined by the immaculate Imams (MesbahYazdy, 1998, p. 88). Whenever, and for whatever logical reason the experts make a conclusion that the leader has lost the requisites for leadership or there is somebody else stronger and better than him, and the leader is automatically ousted and the experts must declare his dismissal and replace him by another jurist (MesbahYazdy, 1998, p. 74). There is no stipulation in the constitution which indicates the selection of the leader by the experts, but there are evidences that prove the theory of appointment (MesbahYazdy, 1998, p. 54).

In brief, based on this view, neither people nor the experts have the right to legitimize a leader. The only function they have is to admit the good choice already made by God and innocent Imams. In this view, the experts, as witnesses and justifiers, put it forth before the people that they have recognized the real and genuine leader and people accept the claim with their votes to the experts (Hajjariyan, 2000a, p. 662).

On the other side, another group who deemed the Experts Assembly as a medium in leader's election by the people and believed that its only difference with the presidential election is that it is run in two levels. Thus, according to this view, the leader is elected by the people and the Experts Assembly works as the mechanism of the election not recognition. In this view, the Experts Assembly plays the role of a mediator, i.e. an agreement about republican and leadership is made between people and the leader. And the experts are specialists who are chosen as attorneys of people that transfer the right of national sovereignty to the leader (Hajjariyan, 2000a, p. 662). Therefore, the main task of the experts is to elect and legitimize the Jurist. The experts have obtained this right directly from the people and in the framework of the Constitution. To prove their argument, this group referred to the word "dismissal" in the article 111 and put it in contrast to the word "election". On the other hand, in the article 107 the task of the experts is said to elect but not to unearth the leader. Supporters of this theory referred to the last letter of Imam to Ayatollah Meshkini. It was explicitly stated in that letter that "if people have voted to the Assembly so that they could identify a fair Jurist for leading their government, and when they do it, it necessarily means that the people would accept him. In this case he is the guardianship Jurist and his orders are effective" (Khomeini, 1992, p. 39). Also, this group believed that the legitimizing function of the Experts Assembly could be understood from Imam's congratulatory message to the Assembly sent for its inauguration day. In this letter he declared, "according to the article 107 of Islamic Republic Constitution the blessed Experts Assembly, elected by the votes of the great nation of Iran, with a number of scholars of Islam and in order to identify the leader or the leading council is inaugurated; An Assembly which plays an essential role in prolonging the Islamic Republic system and legitimizing it" (Khomeini, 1992, p. 47). Based on this letter, this group deduced that Imam believed the legitimacy of the Jurist's rule comes from people and considered voting as the mechanism for electing the members of the assembly (Ganji, 2000b, p. 89). This stand is contrary to the views of the first group who believed that people's vote for the Experts Assembly have referred to "justifier

Discussions on the issue of guardianship and its secondary related subjects were prolonged by groups, parties, organizations and particularly the press activists for a year, and then changed to extensive quarrels. Officials, too made use of the tribunes available to them and each, in his turn, tried to defend his own views. Finally, by Khatami's statements - as the president of the country - and the Leader's confirmation of his words the quarrels receded and began to fade out of the press discussions. Emphasizing the stipulated position of the guardianship of Jurist in the Constitution, he invited all to be loyal to it and addressing all supporters of different theories declared that what matters in the stage of society and practice is the Constitution itself. For that reason, anybody with any understanding and interpretation of guardianship must be loyal to it as it is determined in the Constitution. To study more about these debates it would be helpful to read newspapers like Resalat, Salam, Sobh-e-Emrooz, Keyhan, and Shoma that all include most of the theories and criticisms.

\subsubsection{The Guardian Council and Approbation Supervision}

One of the controversial issues after 23 May was the way of supervision employed by The Guardian Council in different elections. According to the article 99 in the Constitution of Islamic Republic of Iran, the supervision on the elections for the Experts Assembly, Presidential Election, the election for The Islamic Consultative Assembly and referenda is a task of the Guardian Council. In the past, the type of supervision implemented on 
the elections has always been the subject of argue among different political groups and wings, and this it has been a hot issue before every election. But when was the time to near the election for the Sixth Assembly and the election for the Experts Assembly in 1999 and the competition among political wings to gain more seats in the Assembly, controversies was made through publications and articles over the type of supervision evolved to a great deal.

The main confrontation in this quarrel was between two groups, i.e. those who supported the Approbation Supervision and those who objected to and criticized it. Since there was no indication about the kind of supervision in the Constitution and the degree of the Guardian Council's interference was not clear, the issue remained unclear.

The situation was unchanged until before the election for the Fourth Consultative Assembly when Ayatollah Rezvani, the head of the central board of the Guardian Council for supervising the election, enquired the commentary of The Guardian Council about the Constitution Article 99. On 22 May 1991, the Secretary of the Guardian Council declared that the supervision in question was an Approbation Supervision and included all executive steps among them verifying or rejecting the competency of the candidates (Mohtashamipour, 2000, p. 203). Making use of such interpretation, in the election for the Experts Assembly, the Guardian Council rejected the competency of many political figures from its opposition wing. This included figures like Karroubi, Khalkhali, Khatami, Hadi Khamenei and others. Also, in the election held in 1992 for the Fourth Consultative Assembly, some competent politicians like Behzad Nabavi, Rajaee and Ibrahim Asgharzadeh were rejected. The elected candidates for this very Assembly passed a bill to consolidate and legalized the Guardian Council's approbation supervision. When, in 1995, on the issue of approbation supervision, Abdollah Nouri who was the Interior minister of President Hashemi at that time said, "at the beginning, The Guardian Council was supposed to supervise and nobody was to interfere, then it was decided that only the Guardian Council has the right to interfere in the election" and because of this statement he ousted (Ghoochani, 2000, p. 118). There was no significant resistance against the Guardian Council till before the election for the Sixth Consultative Assembly. In fact, after that commentary and law, the Guardian Council, referring to lawfulness of approbation supervision, has executed approbation supervision in all elections. On the other side, critics have tried to change such supervision through presenting legal and political reasons. The defenders of the approbation have the following reasons for executing the approbation supervision:

1) The article 99 has not specified the type of supervision; the Guardian Council is the interpreter of the Constitution and the interpretation of the Council determines approbation.

2) The law of approbation supervision is ratified by the Consultative Assembly and if it is going to be nullified it should be nullified by the Consultative Assembly.

3) Supervision without the authority to show views and without a pressing lever is not logically correct.

4) The Guardian Council is the guard and the preserver of the electoral institutions from penetration of the aberrant, and if the Council has no right to reject competencies and execute its power it cannot perform its duties.

Yet the opponents of approbation supervision, who considered it against the interests of the Islamic Republic system, presented the following reasons:

1) The Guardian Council does not have the right to interpret the Constitution to the benefit of its authorities.

2) The interpretation made by the Guardian Council is against the article that stipulates power separation. In fact, it causes to one of legislative institutions to interfere the performance of an Executive institution, which is the Ministry of Interior.

3) In the Constitution, the duty of the Guardian Council is stipulated as supervision, but with such interpretation, it finds a free hand to interfere in the election's procedure.

4) The experience of the past elections show that relying on such interpretation, this Council which based on some reasons, has rejected the competency of many figures who have not been in the same political and ideological direction. The outstanding example was the elections held for the Experts Assembly and the Fourth Consultative Assembly. Thus "approbation supervision is a filter through which some have found the authority to - in the framework of their own views and evaluating system - deprive others from candidacy, and is finally against participation and republican" (Baghi, 2000, p. 180).

5) Legalizing the approbation supervision is against the article of power dissociation in the Constitution and the Fourth Consultative Assembly has had no right to do as such. 
6) Based on such interpretation, "the Guardian Council has also the duty to verify or reject the competencies, which is a completely executive issue, but the problem is that when the rights of people are violated by the executive organization, the violated right can be compensated for upon referring to the supervisory authority, but when the same right is violated by the Guardian Council there is no authority capable of supervising and vindicating the violated rights" (Mohtashamipour, 2000, p. 140).

7) The ratified law of the Discernment Expediency Assembly on obliging the Guardian Council to offer lawful and written reasons for those whose competencies are rejected is, itself an evidence for the unlawful rejections performed by the Guardian Council in past elections.

8) The Guardian Council may make mistakes in verifying or rejecting the competencies. Thus there should be an institution with the ability to control it so that the rights of the citizens are not violated and the election does not find the approbation form.

9) The history of the Guardian Council in the election run for the first Consultative Assembly does not indicate any trace of such authorities held by the Council.

In any case at the time of election for the Sixth Consultative Assembly, due to the approbation supervision, the guardian council nullified the votes of about 534 ballot boxes containing around 720000 ballots of citizens in Tehran. This had caused some changes at the bottom of the list of Tehran's representatives (Tajzadeh, 2001, p. 253). Yet, discussions on the type of supervision implemented is still open and before every election it is put forward and quarrels are made on it.

\subsubsection{Critique of Hashemi Rafsanjani's Performance}

Ali Akbar Hashemi was the head of the first and second Islamic Consultative Assembly and the president of Iran from 1989 until 1997. He is one of the system's most influencing politicians and has played a pivotal role in political events. He was once the commander during the war between Iran and Iraq (1980-1988) and eventually become the country's Construction Hero. He is now the head of Experts Assembly and also the head of Discernment Expediency Council who plays an important role in settling the disagreements between the Consultative Assembly and The Guardian Council. He also gives the leader consultations on complex cases in the system and along with the council he supervises and suggests some large-scale policies of the Islamic Republic system before the leader. But the 23 May event, which some believe was the outcome of his endeavors and efforts in the period of construction, had no favorable consequences for him. The reason was that the open political atmosphere paved the way for the deepest and harshest criticisms towards his operations during the war and construction period. Therefore, he answered the questions that nobody dared to ask in the past.

Considering this subject, there were again two opposing groups that arrayed face to face. In one side were the critics of Hashemi and on the other his supporters. The critiques are about some important issues. Among them were the management of the holy Defense, the economic operations of Hashemi's government and the performance of Ministry of Intelligence in his tenure. On the other hand, his supporters, from a variety of doctrinal spectra defended his performance from different angles.

\subsubsection{The War}

Hashemi's criticizers believed that prolonging the war after conquering Khorramshahr was politically and militaristically wrong and the fighting should have been stopped at the time. According to Ahmad (Khomeini's son) Imam Khomeini was against the prolonging of the war and because Hashemi had the responsibility to direct the war, he is responsible for the losses caused by the war. They also believe that in 1981, some Arab countries had sent messages indicating that they were ready to pay 60 billion dollars as the compensation for the losses and casualties caused by the war if Iran had ignored Saddam's punishment. Since Hashemi had not accepted this suggestion, the country's interest had been damaged and it had lost the possibility of a better peace (Ganji, 2000a, p. 124).

Answering questions about paying indemnity and accepting the armistice Hashemi said, "There was no message, but people talked about it in some gatherings... I was not the commander in charge of the war, they were saying general things, it was not clear who wanted to put an end to the war...but the main issue was related to Imam himself. He wanted to continue fighting till the time Iraq's case is resolved...he would not agree our forces enter the Iraqi territory, but would not agree to stop fighting either". "After a long session of discussions between Imam and the commanders of both army and Guard Corps, he gave his consent for the military forces to enter only into non-residential locations in the Iraqi territory"(Rafsanjany, 1999, pp. 88-96). In this way, Hashemi introduced Imam as the real commander in the war and a person that could decide on prolonging or stopping the war. 
To declare the main reason for accepting the Resolution 598 which was not discussed much at that time, Hashemi stated, "Our problem started when government wrote to Imam and officially stated that it would not be able to pay for the war expenses any longer. Also, The Guard Corps wrote to Imam that the United States was entering the operations and if we were to fight, more support was needed... more important was that attacks on ordinary people and cities far from the fronts were becoming more serious than before... so there were four crucial points: it was clear that the United States would gradually enter the war; the government declared that the country's budget cannot support the war; there were some essential needs at that particular time; and ordinary people and non-military centers were under serious threats" (Rafsanjany, 1999, pp. 89-98). In this way, answering those who criticized the policy of prolonging the war or even stopping it, Hashemi believed that Imam Khomeini was the strategist of the war and introduced himself as only the executor.

After the clamorous article "the Red Eminence..." he answered to the critiques at the time of the Friday Prayer on 21 Jan 2000 and said, "I consider this newly created wrong political way as a dangerous thing because to gain some votes from the people or uninformed youngsters they question the past honors of the revolution. This is a very high treason. What kind of justification is to say that the war, the holy war, fought during eight years were a disaster for the society and a weak point for the revolution? Whom do you serve? To whom you, unfairly, are selling your country, nation and honors? One of the worst things happening today is questioning the war which is the country's honor."

However, these decisive answers were followed by another article written by Ganji that referred people to some parts of Hashemi's interview in 1983. In that interview Hashemi had said: "We want the indemnities to be paid by Iraq's Ba'th Party and are not willing to accept it from other countries [...] and what unfair man could be found to say that Islamic Republic should not demand the retribution of the transgressor and the punishment of Saddam as well as the elimination of Ba'th Party from the history of Iraq? How can we answer these self-sacrificing war invalids if Saddam remains in power tomorrow? Nothing except for the fall of Saddam and the establishment of an Islamic ruling system in Iraq can soothe the hearts of the war's martyrs and invalids' families. Whatever material indemnity that we gain cannot be compared to the tremendous damages that we have suffered." In his article Ganji asks on Hashemi's answers: "Is it not that damages caused by the war had 100 billion Rials and that these tremendous irreparable damages would make the economic situation worse? Is it not that the main reason for the bitter economic situation was the heavy expenses of the war? And is it not that Hashemi - after the conquest of Khorramshahr - played an important role in keeping that situation unchanged? But today the Red Eminence [Hashemi] refers the questions he must answer to Imam and says that he did not allow anybody to talk about it." (Ganji, 2000a). This clash going on among Hashemi, his supporters and his criticizers and has become heated as the time for the Sixth Consultative Assembly's election become nearer. Each day, there were new points added and discussed by the parties involved in the debates. The conclusion was that the criticism of Hashemi's performance in the area of war (holy Defense) was, in fact, criticizing the large-scale policies of the Islamic Republic and criticizing Hashemi was an excuse to break the taboo of uncriticizability of epic of the holy Defense that lead to hot debates about one of the most important subjects in the history of Islamic Revolution.

\subsubsection{The Construction Period}

Criticizing the economic policies during the Construction period was not a new thing. From 1991 onward, many economists and experts from different political wings had explored and criticized policies like modification, privatization, equalizing the currencies' rates, taking loan from the World Bank, and borrowing from other countries. Iran-e-Farda as a publication and Salam as a newspaper were the main channels for the criticism on economic performance of Hashemi's economic policy before 23 May. Issues such as inflation rate, the value of national currency, national debts, speed of economic changes, advertising consumerism and luxury, unfinished plans, undisciplined privatization and so on were amongst the criticisms on Hashemi's Construction government after 23 May.

In an interview, Hashemi has responded to some of these criticisms. Answering those who criticized the decision of having single-rated currency and its consequences for the country's economy, Hashmei said,

"Making the foreign currency single-rated is related to the last years of the first plan. In the early years it was not single-rated. We had an official rate equal to 70 Rials, and there were also a rate equal to 600 Rials and another free rate in the market. Step by step we made all these close to each other. The important thing that happened was that we legalized importing without currency transference, and this was related to our foreign commercial policy." (Rafsanjany, 1999, pp. 141-142). 
Answering to the critiques on borrowing from other countries during his tenure and the loans that had remained unsettled afterwards Hashemi said, "12.5 billion dollars were the foreign obligations related to the previous government and 30 billion dollars were the finance received from foreigners, but the plan was to receive that money during the first five years and return it during the second five years." In Hashemi's view, this sum was paid off. As Hashemi states, "whatever we received as the foreign commerce balance is close to what we delivered." Thus according to Hashemi "the gentlemen's [critics'] claim, continued to be stated, that the country owes 30 billion dollars is a historical big and scandalous lie, we started with an obligation of 12.5 billion dollars and at the end an amount of 5 or 6 billion dollars is due to us and we do not owe anything, these criticisms are baseless" (Rafsanjany, 1999, pp. 172-174).

Hashemi believed that the extent of construction done at his tenure has had not any precedence from the time of the Median Empire. In their turn, and responding to this exaggeration, his critics declared with exaggerations that the Construction period has been only a host of slogans, inflation, loans, currency depreciation and the split between classes. To be aware of critiques and their related answers, it would be helpful to take a look at the headlines and articles written by people like Hossein Azimi, Abbas Abdi, Akbar Ganji, and the interviews and speeches made by Mohammad Hashemi, Fayezeh Hashemi, and Hashemi Rafsanjani himself.

\subsubsection{Ministry of Intelligence}

The horrible murders of intellectual and political activists in autumn 1998 that led to one of the most controversial subjects in the reformists press became one of the reasons for criticizing Hashemi Rafsanjani. Newspapers like Sobh-e-Emrooz, Salam, Khordad, and writers like Ganji and Hajjarian had tried assiduously to recognize the agents involved in these crimes. Finally, Saeed Imami's group was recognized by the continuous search of the press, the government and the Supreme Leader, and the case was detected. However, the case was not closed with the announcement made by the ministry of intelligence. The critics and intellectuals believed that the case of chain murders was not limited to the four murders committed in autumn 1998. Rather, all dubious murders of writers and political activists during 1990s should be prosecuted. This problem gradually involved Hashemi and forced him to give an answer.

The critics insisted that during Hashemi's tenure, Saeed Imami had gotten high position in the Ministry of Intelligence when Ali Fallahian was in office. Since many murders in the past were related to Imami's clique, Hashemi was supposed to be responsible, and as the president of the time, he should be responsive for the past murders as well as those happened in 1998. In response to these critiques, Hashemi declared, "during my tenure, the Ministry of Intelligence had experienced its cleanest time. The Ministry of Intelligence at my time was greatly infiltrated, and was cleared from many things." These answers provoked Hashemi's critics to bring more reasons indicating his responsibilities in the case of the murders and the deviations of the Ministry of Intelligence at the time of his presidency. The most outstanding critic was Akbar Ganji who in his famous article, "The Red Eminence" claimed that Hashemi's claims were incorrect. He wrote:

"During eight years of Hashemi's presidency nearly eighty persons were murdered by intelligence groups for political reasons, the most notable of whom were Saeedi Sirjani, Barazandeh, Miralaee, Tafazoli, and some others. Furthermore, the kidnapping of Faraj Sarkoohi, and the plan to steer writer's bus down into the deep valley had happened at the same time. Identity (Hoviiat), the broadcast program, was made by Saeed Imami and broadcasted on the governmental television". "Thus Hashemi, himself, knows better than others that Saeed Imami's group at the time of Ali Fallahian's ministry had been active when Hashemi was in office, because Hashemi admits that Saeed Imami's group was against his policies to wipe tension off, had taken missile to Belgium and had endangered Iran's national interest. But Hashemi did not want or could not remove this cancerous swelling from the Ministry of Intelligence. In addition, the disciplinary court had ousted him (Saeed Imami) from his post as the deputy of intelligence, but he was later appointed as a consultant and had committed some later horrible crimes. Who is responsible and responsive? In any case, Hashemi should be responsive for some of the complexities created in the Ministry of Intelligence under his supervision so that the public could see the extent of Hashemi's liability" (Ganji, 2000a, pp. 122-129).

By the end of the election for the Islamic Consultative Assembly and Hashemi's resignation to join the Assembly much criticisms were put before him. However, many of the critics faced heavy files of accusations and were sent to jail to pay the cost of their red lines crossing. Many of the critics at that time, such as Akbar Ganji and Abbas Abdi were imprisoned and many others had to be silent. There is no sign of those bold criticisms at the present time and perhaps we can claim that Sadegh Zibakalam's prediction has come to be a correct one. In the process of Hashemi's criticisms, Zibakalam wrote an article entitled "Mosharekat Front, 23 May, Leftism and Hashemi Rafsanjani" in which he criticized the criticizers, stated that the harsh criticism of 
Hashemi was not correct. He believed that the unfair criticism of Hashemi had made him inclined towards the right wing and this would be a great loss for the reformist wing. He believed that the presence of Hashemi in the Consultative Assembly would give weight to the reformists' assembly. This is because of the Guardian Council would not be able to make him ineffective since Hashemi is an influential man. It is believed by them that Hashemi has a great influence in the Islamic Republic's system and he does not let the Assembly to get weak. Zibakalam even believed that Hashemi is a moderate reformist. However, figures like Akbar Ganji, Seifollah Baniasadi and Abbas Abdi had written articles and evaluated his analysis as incorrect (Zibakalam, 2001).

The criticisms of Hashemi caused to put important issues before the public. Hashemi was criticized and was forced to answer, but his answers were not enough to convince the public. Thus, in spite of gaining a seat in the Consultative Assembly, albeit after that 500 ballot boxes were nullified by the Guardian Council, he resigned from joining the assembly and preferred to sit in the Discernment Expediency Council and say the final word when the disagreement rose up between the sixth Assembly and the Guardian Council, though his words were not to the benefit of the reformists.

\subsubsection{Military Forces and Politics}

"My emphatic counsel to the armed forces is to observe abide by the military rule of non-involvement in politics. Do not join any political party, group or faction. No military man, security policeman, no Revolutionary Guard or Basij may enter into politics. Stay away from politics ...” (An extract from Imam Khomeini's will addressing the armed forces)

"The Islamic Revolution Guards Corps, organized in the early days of the triumph of the Revolution, is to be maintained so that it may continue in its role of guarding the revolution and its achievements." (The article 150 of the Islamic Republic Constitution)

Some events and speeches of the guards' commanders Safavi and interpretations of the two above-mentioned subjects, caused discussions in the press and public about the position of Islamic Revolution Guards Corps in the system of Islamic Republic.

The speech made by Major General Safavi was the starting point of argue between his supporters and the reformist press. In a seminar held in Qom, on the issue of press atmosphere and endangering the national security, he said, "these days some newspapers and publications endanger the national security. I talked to Mr. Mohajerani [the minister of the Ministry of culture and Islamic guardian at that time] for an hour and told him that his way is threatening the national security. We are trying to uproot counter-revolutionary wherever they are. Some must be beheaded, we must cut the tongues of some, our sword is our tongue" (Shalamcheh weekly, no.30). After this speech and when some of its parts were published in some publications, there were some objections made to the speech. First, the speech was announced to be distorted and then it was announced that printing it had been illegal due to the fact that it had been form classified secret documents, but after some days passed the Public Relation Department of the Guards Corps published a proclamation in which along with implicitly defending the Major General, new accusations and threats for the press were put forward. The proclamation reads: "Emphasizing the need for more alertness than before in part of the people against the implicit and explicit conspiracies of the nation's enemies the Islamic Revolution Guards Corps warns that part of the press and the suspected poisonous pens who taking advantage from the open atmosphere of the country and the patience and decency of the revolution's forces are trying to inject their sick thoughts and polluted ideas and endeavoring to deviate minds from the conspiracy and enmity of vowed enemies of the Islamic Iran and - from time to time - relying on the weak, baseless materials and exaggeration of the minor events are trying to make cracks in the strong united lines of the people. We warn them to stop this way and not to feed the enemy's media." (Hamshahri daily, 4 May 1998).

In an interview, Major General Safavi emphasized and reiterated his idea that some of the reformist writers and newspapers are related to some cliques and threatened to introduce them to the public. Following these discussions, the Right wing newspapers started to praise Safavi and declared that in the cultural front, too, he has acted in the right time. Many of his supporters emphasized that according to the Constitution the major task of Guards Corps is to guard the Islamic Revolution's achievements and knew it as a permit for Guard Corps' interference in politics. Accordingly they greatly supported his verbal confrontation with the reformist press.

In response, referring to Imam's words in his will about the prohibition of Guards Corps interference in the area of politics the critics declared that the speeches and proclamations were against Imam's way and even on the contrary to the Constitution. In his article entitled "Mr. Rahim Safavi! Let Political Figures Define Security", Morteza Mardiha criticized Safavi's words and declared his worries about running the country in the way that garrisons are disciplined. In one part of the article he wrote, "I stand shivering when I imagine that a country is going to be run by soldiers. Not shivering because they are going to cut my tongue or take my head off. But 
because they look at the society like a garrison in which they like to give a strong command so that not only the eyes, boots and hands" (Mardiha, 1999, pp. 31-32).

After the Guard's proclamation supporting Safavi, in an article entitled "A Kindly Warning to Dears in Guards Corps", Mohtashamipour reminding Imam's will and calling the proclamation in favor of one wing wrote: "the esteemed commander of Guards Corps know well that according to the law and the infallible idea of the Eminent Imam and the great Leader, the armed force including the Guards Corps must not have a membership or relation to any group and must not support one as well... the responsibility of any deviation or disobedience of this way is upon the commander of the body" (Mohtashamipour, 2000, pp. 242-239). Moreover in his article entitled "What is to the best interests of Guards Corps and what are its responsibilities?" Hajjarian criticized Safavi's speech and his reasons for interfering in the political and intelligent affairs and answered to Safavi's claims on the Guards Corps tasks. Hajjarian writes: "this reasoning put forward repeatedly by this gentleman [Safavi] and some other Corps' commanders are in no way according to the law behind the establishment of the Guards Corps". In addition, to say merely that Constitution identifies the Guards Corps as the body to guard and defend the Islamic revolution and its achievements is not sufficient to consider counter-overthrowing, anti-spying, intelligence and security missions for the Guards Corps. If it is to interpret the revolution's achievements in an extended way then perhaps we can fabricate economic, political, ideological and pedagogical missions for the Corps". (Hajjariyan, 2000a, pp. 596-603).

After much discussions among the press, arguments about Safavi's speech gradually receded through shutting down the reformist press. But the important point in these discussions was that most of the political activist worried about militarization and the interference of militarists in the stage of Iran's policy and were sensitive to the danger of such interference. Also the quarrels indicated that certain inclinations existed inside Guards Corps toward one of the country's political wings. Although it remained obscure, one point became clear that in addition to guarding the borders of Islamic republic the Guards Corps considered for itself some specific missions to support institutions and political groups holding certain ideologies and acts in a way to perform this mission; a characteristic not found in the army. Anyway, the interference of military forces in politics and party competitions is one of the most important damages to a civil society limiting its general atmosphere in Iran. It makes the free and equal communicative relations impossible and is a serious threat to political and democratic progress.

\section{Conclusion:}

23 May 1997 provided an open cultural and political atmosphere through which many issues, institutions and figures were discussed and criticized in the framework of a press dialogue. It was the first Iranian experience in communicative actions that led to a public sphere. Also it was the first crucial resistance by civil society against political power that criticized the process of colonization of the Iranian Lifeworld. This study illustrated Habermas's notion of communicative power can help developing countries to empower civil society. Although that public sphere bounded by state power but it proved the power of civil society particularly the effect of the press in expanding of public sphere in Iran.

What has been brought here is a small part of the debates and to have more information one should refer to the press published at that period. For the first time after the triumph of Islamic Revolution serious and hot discussions about important issues of the society were made. These discussions, if continued, could end the elites' serious disagreements about encompassing political, economic and cultural issues in the society and make a relative consensus among them. These debates could create a passage for the transition of the society from conflict to concord to agreement. In this way important issues like the relation between freedom and law, democracy and religion, government and opposition, election and selection, religious legitimacy and public legitimacy, violence and tolerance and moderation, parties and government, plurality or the lack of religious plurality, ideology and religion, political crime, political court and jury, constitution and the institution of guardianship of Jurists, the relation or the lack of relation to the world's powers, political and economic development, clerics and people and so many other important fundamental issues could be put and judged in an atmosphere of bilateral dialogue in the press and public gatherings. In this way all logical and illogical sides of each group or wing's claims could be identified and judged by the public. But due to reasons that needs to be discussed in another article the dialectical atmosphere changed to a quarrel and each side of the debates especially those who lacked enough logic to support their arguments - started to denigrate the other party's wing and personalities. Also, to evade giving an answer to the people the influencing men who were criticized and forced to respond in such atmosphere, started to threat and delimit the writers and publications and tried to accuse them with accusations like having intentions and conspiracy. The result was that many of these issues remained unsolved and most of the debaters of one side are now either in jail, in abroad or deprived from having 
a permit to run a newspaper and some of them witnessing the fate of their friends like Akbar Ganji, Emadoddin Baghi, Shamsolvaezin, Morteza Mardiha and Abdollah Nouri... preferred to be silent.

Although there is no sign of that prosperous time for the press today, many of political and intellectual debates that were taboos, not to be discussed, changed to public issues to be discussed in the public sphere of Iran's society and this is a great advantage for the civil society of Iran.

\section{References}

Aghajary, S. H. (2002). Hokumate dini va hokumate democratic (Religious system and Democratic System). Tehran: Zekr.

Amoli, A. J. (1999). Velayate Faghih: velayat, feghahat, va edalat (The Primacy of Faghih, Velayat, Feghahat, and Justice). Qom: Nashr-e Asra.

Baghi, E. (2000). Hoghooghe mokhalefan: tamrine demokrasy baraye jameeye Irayn (The Rights of the Oppositions: Practicing Democracy for the Iranian Society). Tehran: Sarayi.

Flynn, J. (2004). Communicative Power in Habermas's Theory of Democracy. European Journal of Political Theory 3, 21.

Ganji, A. (2000a). Alijenab Sorkhpush va Alijenaban Khakestary (The Red Eminence and Grey Masters). Tehran.

Ganji, A. (2000b). Talaghiye fashisty az din va hokoomat (The Fascistic View of Religion and Government) Tehran: Tarhe-now.

Ghoochani, M. (2000). Pedarkhandeh va chap-haye javan; mobarezeh baraye naghde ghodrat (Step Father and the young Leftists; Fighting to Criticize the Power). Tehran: Nashr-e Nay.

Habermas, J. r. (2006). Political Communication in Media Society: Does Democracy Still Enjoy an Epistemic Dimension? The Impact of Normative Theory on Empirical Research. Communication Theory 16, 15.

Hadavi, M. (2002). Velaiat va Dianat (Guardianship and Honesty). Qom: Khane Kherad.

Hajjariyan, S. (2000a). Jomhooriyat; afsoonzodayi az ghodrat, (Republic; Demythologizing Power). Tehran: Tarh-e Now.

Hajjariyan, S. (2000b). Tavan-e eslahat (The Penalty of Reforms). Tehran: Zekr.

Kavakebiyan, M. (1999). Mabaniye Mashrooeeyat dar nezam-e velayat-e faghih (The Principles of Legitimacy in the System Ruled by Jurisprudents). Tehran: orooj.

Kermany, M. J. H. (2001). Az khordad ta khordad: Arteshe bist melioni cheh goft? Gozidei az maghalat 1376-1380 (From Khordad to Khordad: What did the Twenty-Million Army Say? A Selection of Articles 1997-2001). Tehran: Ettelaat.

Khomeini, R. (1992). Sahifeye Noor (The Book of Light) (Vol. 21). Tehran: Moasese Hefz va Nashre Asare Imam Khomeini.

Kumar, D. (2001). Mass media, class, and democracy: the struggle over newspaper representation of the UPS strike. Critical Studies in Media Communication, 18(3), 17.

Mardiha, M. (1999). Ba Masooliyate Sardabir (Editor in Chief Charged). Tehran: Jameeye Iranian.

MesbahYazdy, M. T. (1998). Porsesh-ha va pasokh-ha: Velayate faghih va khobregan (Questions and Answers :The Jurist and The Experts ). Qom: The Educational and Research Institute of Imam Khomeyni.

Mohammadi, M. (1999). Jameeye Madaniye Irani; bastarhaye nazary va mavane. (Iranian Civil Society; Theoretical Contexts and Obstacles)

Tehran: Markaz.

Mohtashamipour, A. A. (2000). Chand Sedayi dar jameeye rohaniyat (Multiple voices in the Community of Clergymen). Tehran: Khaneye andishe Javan.

Rafsanjany, A. H. (1999). Haghighat-ha va maslehat-ha: Goftegu ba Hashemiye Rafsanjany, be ehtemame MmasoodeSsafiry (Facts and expediencies: Dialog with Hashemy Rafsanjany) (Masood Safiry ed.). Tehran: Nashr-e Ney.

Roodi, Z. (1999). Bahaye Azady: Defaeeyate Mohsen Kadivar dar dadgahe vizheye rohaniyat, (The Price of Freedom: Mohsen Kadivar's Defense in the Special Court for the Clergyman). Tehran: Nashr-e Ney. 
Saleh, S. M. (2000). Jaygahe ghanoon dar nazme velayi: Monazereye matbooaty ba Saeed Hajjariyan (The Position of Law in Velayi Order: Press Panel Discussion with Saeed Hajjariyan ). Qom: Vothugh.

Tajzadeh, M. (2001). Raaye Mardom: mohakemeh va defaiyate Seyed Mostafa Tajzadeh be revayate Babake Dad (The Vote of the Nation: The Trial and Defense of Seyed Mostafa Tajzadeh Cited by Babak Dad). Tehran: Tarh-e Now.

United Nation Statistical Yearbook (1999-2005). New York: United Nation.

Vitale, D. (2006). Between deliberative and participatory democracy: A contribution on Habermas. Philosophy Social Criticism 32(6), 27.

Zakerhossein, A. (2005). Tarikhe Matboate Siasi dar Irane Asre Mashroteh (Iran's Political Press in Constitutional era). Tehran: University of Tehran

Zibakalam, S. (2001). Aks-haye yadegary ba jameeye madany Memorial Pictures with Civil Societ. Tehran: Rowzaneh.

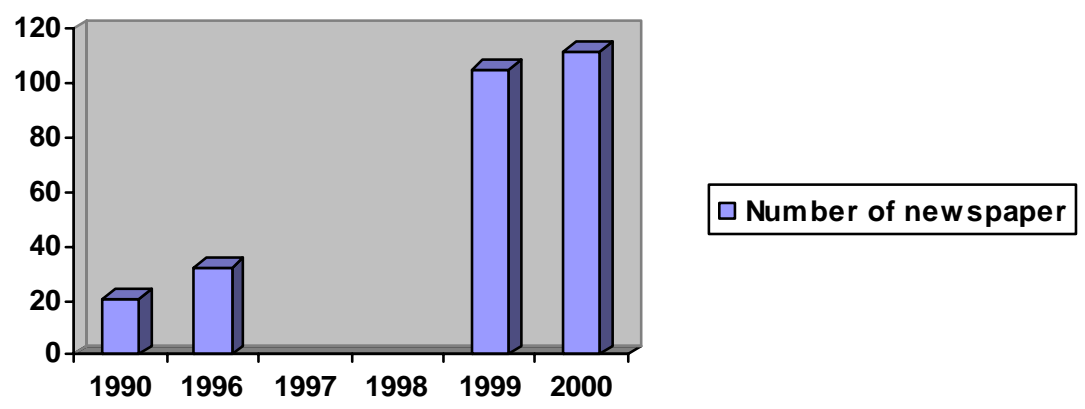

Figure 1. Increasing of newspapers (United Nation Statistical Yearbook, 1999-2005)

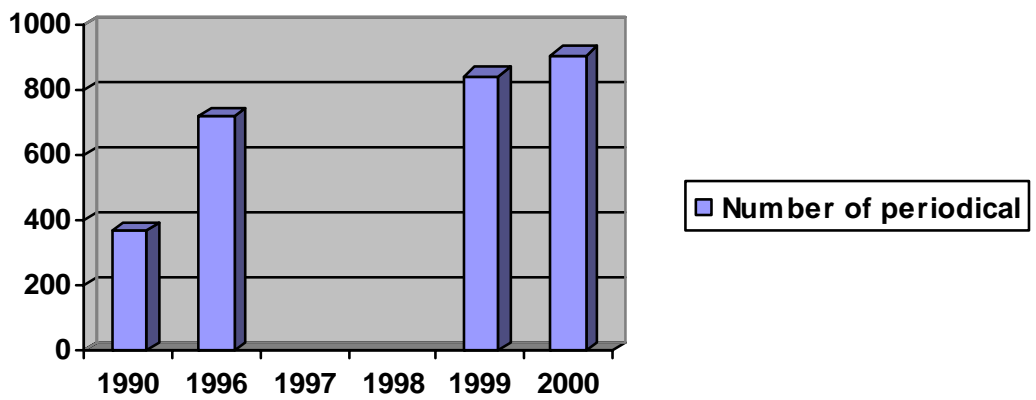

Figure 2. Increasing of periodicals (United Nation Statistical Yearbook, 1999-2005) 